\title{
MUSK wt Allele
}

National Cancer Institute

\section{Source}

National Cancer Institute. MUSK wt Allele. NCI Thesaurus. Code C52178.

Human MUSK wild-type allele is located within 9q31.3-q32 and is approximately $132 \mathrm{~kb}$ in length. This allele, which encodes muscle, skeletal receptor tyrosine protein kinase protein, plays a role in neuromuscular synaptogenesis. 